\title{
Wat nou na verwonding?
}

Book Title:

Wanneer seerkry en God se koninkryk ontmoet

\section{Book Cover:}

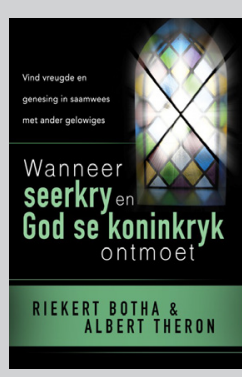

Authors:

Riekert Botha

Albert Theron

ISBN:

978-1-4316-1011-2

\section{Publisher:}

Christelike

Uitgewersmaatskappy, 2016

R129.95*

*Book price at time of review

$\longrightarrow$

Wat nou na verwonding?

Reviewer:

P.J. Vermeulen ${ }^{1}$

Affiliation:

${ }^{1}$ Reformed Church

Wapadrant, South Africa

Corresponding author:

P.J. Vermeulen,

peet@gkwapadrant.co.za

How to cite this book review:

Vermeulen, P.J., 2016,

'Wat nou na verwonding?',

In die Skriflig 50(1), a2157.

http://dx.doi.org/10.4102/

ids.v50i1.2157

\section{Copyright:}

(C) 2016. The Authors.

Licensee: AOSIS. This work

is licensed under the

Creative Commons

Attribution License.

Read online:

口及la Scan this QR

code with your

smart phone or

smart phone or

mobile device
to read online.
Die titel, Wanneer seerkry en God se koninkryk ontmoet, ontlok die gedagte dat dit oor seerkry in die wêreld handel met die belofte van genesing na die interaksie met God se koninkryk. Groot is die verrassing egter om te ontdek dat dit oor die seerkry van gelowiges BINNE gemeenteverband handel.

God se gemeentes is veronderstel om 'n liggaam te wees waar volgelinge in 'n veilige omgewing in hulle verhouding met God en hulle medemens kan groei. As gevolg van die sondige wêreld het dit ongelukkig ook 'n plek geword waar soveel hartseer en pyn veroorsaak en intens beleef word.

Die boek handel oor wat dit beteken om deel van 'n geloofsgemeenskap te wees. Drie dinge is belangrik rondom die verstaan van 'n geloofsgemeenskap:

- 'n Geloofsgemeenskap is God se plan.

- Die mens wil hierdie plan kaap.

- Satan wil God se plan verwoes (Botha et al. 2016:19).

Die onderafdelings in hierdie hoofindeling is die volgende:

- Die gemeenskap moet draers van God se heerlikheid en teenwoordigheid wees.

- Geestelike groei en volwassenheid kom onder die loep.

- Die beskrywing van manifestasies van die vlees wat verwoesting saai en hoe mense verkeerdelik daarop reageer.

Jesus Christus word as die pad na genesing aangedui. Die boek waarsku teen valsheid in die liggaam van Christus en dui aan hoe valsheid uitgewys en prakties uit die Woord van God hanteer kan word (Botha et al. 2016:5).

Die boek het baie meriete. Konteks en teks vorm die basis van die werk. Die tema uit die titel, Wanneer seerkry en God se koninkryk ontmoet, is uiters relevant vir die konteks van ons dag. Die gemeente is veronderstel om plaaslik die liggaam van Christus te wees waar gemeentelede saam kan aanbid en geestelik kan groei. Dit behoort ' $n$ veilige plek te wees waar die heerlikheid van God sigbaar is. Die realiteit in die sondige wêreld waarin ons leef is egter dat baie mense verwonding in gemeentes opgedoen en stukkend, selfs verbitterd kies om hulle geloof in hulle eie klein hoekie te leef, of om onafhanklike gemeentes of huiskerke te stig sonder om ooit die probleem te probeer oplos.

Die teks (Bybel) word vir die verklaring sowel as die oplossing van die probleem gebruik. Die probleem ontstaan wanneer die mens God se plan kaap en met sy eie probeer vervang. Slim vang uiteindelik sy baas en wreek hom oor die planverandering met oneindige ellende, hartseer, pyn en stukkendheid in die gemeente. Die antwoord of reddingsplan word telkens uit verskillende dele van die Woord aangedui.

Hierdie boek se inhoud sal vir alle Christene verrykend en prakties uitvoerbaar wees. Die skrywers skryf vanuit hulle ervaring, wat verskeie kerke, kerkgenootskappe en onafhanklike bedieninge insluit. Die Bybel is die enigste maatstaf wat aangelê word.

Die skrywers se uitgangspunt om telkens God aan die Woord te stel, is prysenswaardig. Hulle glo duidelik dat elke probleem in die gemeente in die lig van die Woord beoordeel kan word. Hulle bied praktiese riglyne wat verwondes kan help om hulle wantroue in 'n gemeente te herstel. Hulle standpunt dat die gemeente die plek is waar gelowiges moet groei, asook liefde en heling van hulle wonde kan ervaar, is Bybels positief en prysenswaardig.

Almal wat verwond is, stel uself oop en word weer heel! 